\title{
THE STRUCTURE OF HEBREWS FROM THREE PERSPECTIVES
}

\author{
Steve Stanley
}

\section{Summary}

The literary genre, rhetorical character and content of Hebrews all provide clues to the structure of the book. In the final analysis none of these should be considered in isolation, but of the three, content is of primary importance. Among the most significant structural clues in Hebrews are the use of Scripture, particularly Psalm 110, the use of the 'word of exhortation' form, announcement of subject, the use of various genres within the larger framework of the homily and the fluctuations of theme and content. Hebrews can be divided into three main sections: the superiority of Christ (1-7), the superiority of Christ's ministry (810) and the resulting responsibilities of the people of God (11-13).

\section{Introduction}

'In order to understand correctly the message which the author of Hebrews has left us it is not enough to read his sentences one after the other. One must also and above all figure out the composition of the work as a whole. ${ }^{1}$ Although this seems selfevident, some scholars do not recognise the importance of structure for understanding the book of Hebrews. ${ }^{2}$ Those who

${ }^{1}$ A. Vanhoye, Structure and Message of the Epistle to the Hebrews (Rome: Pontifical Biblical Institute, 1989) 18.

${ }^{2}$ The outline given in F.F. Bruce's original commentary, for instance, is simply topical and shows no concern for an overall structure: The Finality of Christ 1:1-2:18; The True Home of the People of God 3:1-4:14; The High Priesthood of Christ 4:15-6:20; The Order of Melchizedek 7:1-28; Covenant, Sanctuary and Sacrifice 8:1-10:18; Call to Worship, Faith and Perseverance 10:19-12:29; Concluding Exhortation and Prayer 13:1-25; Postscript 13:22-25 (The Epistle to the Hebrews [NICNT; Grand Rapids: Eerdmans, 1967] xix-xxii). In the revised edition of his commentary, however, Bruce does include a footnote on the literary structure of 
do consider issues of structure are by no means in agreement regarding the structure of Hebrews. ${ }^{3}$ This is due in part to the author's ability to construct very smooth transitions, which tend to create inconspicuous section breaks, and the sheer complexity of the author's line of argumentation and hence his structuring of the book. Whatever can be said for the structure of Hebrews, one must admit that uncovering it is a long and arduous process. David Alan Black holds a similar view:

Literary structures, to use a scientific analogy, are like those mysterious species of fish which live on the ocean floor. As soon as they are brought to the surface to be examined, the change in pressure is too great for them, and they explode, leaving their investigators in a state of frustration and bewilderment. 4

After some frustration and not a few explosions, I will endeavour once again to bring this delicate creature to the surface. In this attempt, I will consider the implications of literary genre and rhetorical technique and then offer an interpretation of the message of the book. Finally, from the three perspectives of the author's choice of literary genre, his use of

Hebrews (The Epistle to the Hebrews [NICNT; Grand Rapids: Eerdmans, 1990] xxii).

${ }^{3}$ G.E. Rice ('Apostasy as a Motif and its Effect on the Structure of Hebrews', AUSS 23 [1985] 29-35. [p. 29]) says, 'Beyond. . generalisations, however, agreement on the structure of Hebrews comes to an end. As a result, the message of Hebrews, which all agree is influenced by its structure, becomes the victim of a "structural push and shove". That is not to say that Hebrews' major themes are lost in the discussion. Jesus' divinity, his superiority to Moses and Aaron, the superiority of the priesthood over that of the Levitical system, the superiority of the new covenant over the old, etc., remain; but the fine nuances of the text that enrich our understanding of the major themes are often minimised by the structural divisions suggested by various authors.' See P. Ellingworth, The Epistle to the Hebrews (Grand Rapids: Eerdmans, 1993) for an overview of how Bruce has approached the structure of Hebrews from the perspective of content and Dussaut from the perspective of form, and of Vanhoye who falls between these two.

${ }^{4}$ D.A. Black, 'The Problem of the Literary Structure of Hebrews: An Evaluation and a Proposal', GTJ 7 (1986) 163-177 (p. 163). 
rhetorical devices and the content of his message, I will suggest an overall structure for the book of Hebrews.

\section{Structure and the Literary Genre of Hebrews}

'Establishment of a literary genre is essential for the full understanding of any piece of literature. Hebrews is no exception. ${ }^{5}$ It is clear that Hebrews functions in a way similar to a letter, sent to those known to the author but some distance away (13:18, 22-25), but it is becoming more widely accepted that Hebrews is most fundamentally a homily.

\section{Hebrews as a Homily}

Some who have considered the notion that Hebrews may actually be a sermon have not approved it. Manson considers the epistolary ending of Hebrews as evidence that the book is not a sermon. ${ }^{6}$ It is, however, altogether possible that this ending could have been added to a sermon which was to be delivered and read by another. Davies draws the conclusion that it is best to take Hebrews as a letter since it is addressed to the specific needs of its readers. ${ }^{7}$ This characteristic, though, is as much a part of sermonising as letter writing, as both are forms of personal communication usually tailored to a particular audience. Many others, however, do recognise sermonic elements in Hebrews, and with them I agree. ${ }^{8}$

5J. Swetnam, 'On the Literary Genre of the "Epistle" to the Hebrews', NovT 11 (1969) 261-269 (p. 269).

${ }^{6} \mathrm{~W}$. Manson, The Epistle to the Hebrews: An Historical and Theological Reconsideration (London: Hodder and Stoughton, 1951) 3.

7J.H. Davies, A Letter to Hebrews (Cambridge: CUP, 1967) 2. H.H.B. Ayles (Destination, Date, and Authorship of the Epistle to the Hebrews, 3) also prefers to take Hebrews as a letter.

${ }^{8}$ For example, H.W. Attridge, The Epistle to the Hebrews (Hermeneia Commentary; Philadelphia: Fortress, 1989) 13; H. Braun, An Die Hebräer (Handbuch zum Neuen Testament 14; Tübingen: J.C.B. Mohr, 1984) 2; Bruce, The Epistle to the Hebrews, 25, 26; and R.McL. Wilson, Hebrews (The New Century Bible Commentary; Basingstoke: Marshall, Morgan \& Scott, 1987) $16,17$. 
(1) The Homiletical Nature of Hebrews. Probably the most telling evidence for Hebrews as a homily is the phrase in 13:22 where the writer describes his own work as a 'word of

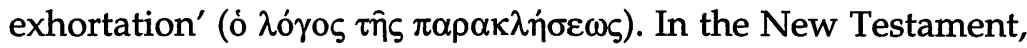
this phrase is used only once again, in Acts 13:15, where it clearly refers to a synagogue speech or sermon. ${ }^{9}$ Lawrence Wills has established that the word of exhortation is in fact a sermonic form in Hellenistic Judaism and early Christianity. ${ }^{10}$ According to Wills, the word of exhortation follows a tripartite structure: 1) an indicative or exemplary section (the 'exempla'), which contains scriptural quotations, authoritative examples from the past or present, or theological exposition, 2) a conclusion based on the exempla and showing their relevance to the addresses, and 3) an exhortation, usually employing an imperative or hortatory subjunctive. An entire sermon may be structured according to this pattern, or the pattern may be repeated several times throughout a sermon. Variations may include temporary digression from this structuring as well as repetition of certain elements of this structure, usually the exhortation, for rhetorical effect. As Wills points out, Hebrews repeats this pattern several times, while at the same time digressing from it and repeating some of its elements out of order. Other examples of the word of exhortation format include Paul's speeches in Acts 13:14-41; 17:24-29; 27:17-35, Peter's sermons in Acts 2:14-41; 3:12-26, the town clerk's speech in Ephesus in Acts 19:35-40, the instruction of the elders in Jerusalem to Paul in Acts 21:20-25, 1 Corinthians 10:1-14, 2 Corinthians 6:14-7:1, 1 and 2 Peter, 1 Clement, the letters of

9Swetnam, 'On the Literary Genre of the "Epistle" to the Hebrews', 261. Cf. also Attridge, The Epistle to the Hebrews, 1; Black, "The Problem of the Literary Structure of Hebrews', 167.

${ }^{10} \mathrm{~L}$. Wills, 'The Form of the Sermon in Hellenistic Judaism and Early Christianity', HTR 77 (1984) 277-99. Cf. the critique of Wills by C.C. Black II ('The Rhetorical Form of the Hellenistic Jewish and Early Christian Sermon: A Response to Lawrence Wills', HTR 81 [1988] 1-18). Black accepts Wills' main thesis saying, 'his presentation is carefully and copiously documented and, in the main, convincingly argued' (p. 2), but Black wants to see a closer connection of the word of exhortation form to Greek rhetoric than Wills. Black's critique, therefore, does not diminish Wills' conclusion that Hebrews is a sermon. 
Ignatius of Antioch, the Epistle of Barnabas, the old LXX version of Susanna, the Testaments of the Twelve Patriarchs, and many more. Several of these examples also demonstrate the practice of repeating the tripartite pattern to form one longer more complex sermon, as well as that of digressing from the established pattern and of repeating elements of that pattern out of order. The presence of the word of exhortation form in a piece of literature, however, does not demand that it be considered a sermon, as made clear by many of the examples cited above, but it does indicate, according to Wills, that the work is either a sermon or sermon-influenced. With respect to Hebrews, Wills asserts that 'the author utilises the [word of exhortation] form and adapts it to a more sophisticated overall structure.'11 Hebrews calls itself a word of exhortation, and this is consistent with the dominant structural patterns of the book. This, along with the truncation of epistolary conventions in Hebrews, would indicate that rather than being simply a sermon-influenced epistle, Hebrews is a sermon turned epistle. 12

Hartwig Thyen has also argued that Hebrews shares the style of a Jewish-Hellenistic homily in the light of its similarities with the Cynic-Stoic diatribe, its use of the Old Testament, and its method of handling paraenesis. Particular homiletical devices highlighted by Thyen.include the frequent change from ' $w e^{\prime}$ ' to 'you' to ' $\mathrm{I}$ ', citation of Old Testament witnesses, reliance on the Pentateuch and the Psalms, methods

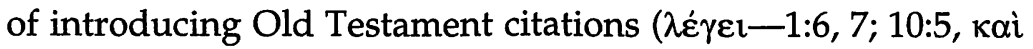

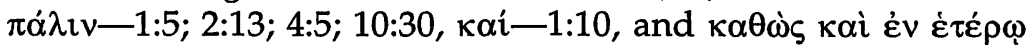
$\lambda \dot{\varepsilon} \gamma \varepsilon \imath-5: 6)$ the employment of several rhetorical devices,

${ }^{11}$ Wills, "The Form of the Sermon in Hellenistic Judaism and Early Christianity', 277-99 (p. 280).

${ }^{12}$ To say that Hebrews is a sermon is not to say that it was written only with a view to being used in a preaching context, although that would be its first and primary function. The literary quality of Hebrews would suggest that the author may have envisioned his work being used outside a formal preaching context as well. In this way Hebrews probably functioned in a secondary sense in way similar to an epistle, just as it was sent in the fashion of an epistle, but its primary identity remains as a sermon. 
attribution of a citation to the Holy Spirit, and more. ${ }^{13}$ Having evaluated Thyen's work with special reference to Hebrews, James Swetnam concludes that his work is valuable though not definitive. Nonetheless, in Swetnam's view, it is a matter of general consensus that Hebrews is in fact a homily. ${ }^{14}$ Finally, David Aune observes several rhetorical devices in Hebrews which would cater to an oral setting: the avoidance of hiatus (when one word ends in the same vowel sound as the beginning of the next, as in 'see easily'), the avoidance of anacolouthon (breaks in grammatical sequence), the use of anaphora (several lines beginning with the same word), careful attention to prose rhythm and alliteration. He also points to 11:32 as an indicator of an oral context for Hebrews: 'And what more shall I say? Time will fail me if I tell of. . .'15

If a first-century sermon can be described as a religious speech delivered before an assembly of believers, and which typically employs rhetorical techniques as described above, then it seems most reasonable to understand Hebrews as a written homily, sent in the fashion of an epistle, but meant to be read aloud as a sermon before a congregation. ${ }^{16}$

(2) The Pastoral Purpose of Hebrews. It would be an error to treat Hebrews as if it were primarily a doctrinal tract or rhetoric for its own sake. In fact, the primary thrust of the book (or homily) is not theoretical but practical, even though doctrine does play a foundational role by providing a basis for the writer's exhortation. The warning passages throughout the book are designed to exhort the readers to faithfulness and obedience, that they might avoid the judgement of God, and

${ }^{13} \mathrm{H}$. Thyen, Der Stil der Jüdisch-Hellenistischen Homilie (FRLANT, n.s. 47; Göttingen, 1955) 10-23, 43-50, 62-72.

14Swetnam, 'On the Literary Genre of the "Epistle" to the Hebrews', 265, 266, 261.

15D. Aune, The New Testament in its Literary Environment (Philadelphia: Westminster, 1987) 212-214.

16J.L. Bailey and L.D. Vander Broek (Literary Forms in the New Testament [London: SPCK, 1992] 193) cite Hebrews as an example of a $\mathrm{New}$ Testament sermon saying, 'The sermon form found in Hebrews most certainly reflects the structure of sermons preached in the early church and as such indicates its link with the world of rhetoric.' 
the last three chapters of Hebrews clearly flow from a pastoral concern for the readers' spiritual understanding and wellbeing. Hebrews does not share the view common today that thinking theologically is too difficult for the average Christian, but theology is not the driving force behind the book. Passages such as $2: 18 ; 4: 15,16 ; 5: 12-14 ; 10: 22 ; 12: 1-4 ; 13: 1-10$ testify to the author's heart-felt, pastoral concern for his readers; this is what drove him to write, and this is what drives his sermon. 17

In the light of this, it would be misguided to look for the climax of Hebrews in its doctrinal parts, and equally questionable to describe the message of the book without highlighting its paraenetic focus. In Hebrews we find a sophisticated view of the Christian faith: it is at one and the same time to be rooted in an informed understanding of theology, and reflected in a unique lifestyle of fidelity. To understand the message of Hebrews, then, it is important to recognise that all of its theologising serves the purpose of providing a firm basis for its exhortation, which is the point of the book.

\section{Hebrews as an Exposition of Psalm 110}

The application of Psalm 110 to Christ represents one of the earliest Christian traditions. In fact, according to Mark 12:36 Jesus himself suggests that Psalm 110:1 is a reference to the Messiah. ${ }^{18}$ Many of the New Testament writers did not find it difficult to appreciate the implication that Psalm 110 was messianic, and therefore that it could be applied to Jesus, as indicated by quotations of and allusions to the psalm in passages such as Acts 2:34; Romans 8:34; Ephesians 1:20; Colossians 3:1; and 1 Peter 3:21. Similar quotations and allusions to Psalm 110:1 and 110:4 are scattered throughout Hebrews as well $(1: 3,13 ; 2: 5,8 ; 5: 5,6,10 ; 7: 1-10,17,20 ; 7: 28-8: 2$; $10: 12,13 ; 12: 2)$.

${ }^{17} \mathrm{Cf}$. B. Lindars ('The Rhetorical Structure of Hebrews', NTS 35 [1989] 38240 [p. 384]) who says, '...the author is dealing with an extremely urgent practical situation which demands his utmost skill in the art of persuasion, if disaster is to be averted', and M. Rissi, Die Theologie des Hebräerbriefs (WUNT 41; Tübingen: J.C.B. Mohr, 1987) 1, 21.

18See also Mt. 22:44 and Lk. 20:42. 
Allusions to Psalm 110:1 can be found as early as the prologue of Hebrews (1:3) and as late as 12:2. In chapter 1, the well-known catena of quotations in verses 5-13 ends with Psalm 110:1, the author finally making the connection between Psalm 2:7 (Heb. 1:5) and Psalm 110:1 (Heb. 1:13) by way of several Scripture quotations. He does this in order to show, among other things, that it is the Son who is spoken of in Psalm $110: 1$. This is so that he can develop the concept of Son throughout the next four chapters (e.g., 2:6; 3:6; 4:14; 5:8), make the connection between the Son and the priest in the order of Melchizedek (from Ps. 110:4) in 5:5, 6 and then develop the significance of Christ's priesthood in the order of Melchizedek in chapter 7. The first seven chapters are spent, therefore, making the connection between Jesus as Sovereign Son (Ps. 110:1—read in the light of Ps. 2:7) and Jesus as the priest in the order of Melchizedek (Ps. 110:4), and showing the significance of having a priest who is also a Son. The kind of skilful exegetical synthesis represented by the author's confluence of the two roles described in Psalm 110:1 and 110:4 into the single person of Jesus is characteristic of our author's exposition of Scripture. It is also at the heart of his unique contribution to the early church's messianic understanding of Psalm 110: 'If Jesus is the one addressed in verse 1 , he is equally the one addressed in verse 4.'19 If his readers had no difficulty believing Jesus was the 'Lord' spoken of in verse 1-and they presumably did not-then they should be able to accept that he was also the 'priest' spoken of in verse 4 , but of course, they had not yet adequately understood this.

On the basis of his connection of Psalm 110:1 and Psalm $110: 4$, and therefore the connection of Jesus as Sovereign Lord with Jesus as priest, he goes on in chapters 8-10 to describe the nature and significance of Christ's priestly ministry. Here he develops the doctrinal significance of Jesus' priesthood, building on his exegesis of Psalm 110:4, and using other relevant Scripture passages such as Jeremiah 31:31-34. In the next section, chapters $11-12$, he develops the paraenetic thrust of his argument, driving home the practical implications of his previ-

${ }^{19}$ Bruce, 'The Kerygma of Hebrews', 4. 
ous exposition. And even though paraenesis comes to the fore in this section, he continues to rely heavily on the exposition of Scripture.

Other passages, such as Psalm 95:7, 8 and Jeremiah 31:33, turn up more than once in Hebrews, but never in more than one division, unlike Psalm 110 which can be found in every major division of Hebrews. And no other Scripture passage is alluded to with nearly the same frequency as Psalm 110, which runs 'like a red thread' through the book. Furthermore, an examination of the psalm's place in the development of the author's thought shows that verses 1 and 4 of the psalm actually serve as the backbone of the book. The first seven chapters of Hebrews are all about the connection of Jesus the Sovereign Lord as portrayed in Psalm 110:1 with his role as priest as described in Psalm 110:4 and the significance of Jesus filling this dual role. The next three chapters explore the theological implications of Christ's priesthood, focusing on his once-for-all sacrifice, while the last three chapters deal with the motivational and practical implications of his priesthood. Finally, in the one place where the author offers a clear and straight-forward statement of his point, 8:1, he relies on allusion to both Psalm 110:1 and 110:4. Therefore, although our author relies very heavily on a plethora of scriptural quotations and allusions, it is Psalm 110 that stands at the core of his message. To put this in different terms, Hebrews, as a homily, is most fundamentally an exposition of Psalm 110:1 and 4.20

\section{The Structural Implications of the Use of Psalm 110}

Since Hebrews is most fundamentally a homily, which is an exegetical and practical treatment of Psalm 110 and several other Scripture passages, it is my contention that the use of

${ }^{20} \mathrm{Cf}$. Bruce, 'The Structure and Argument of Hebrews', SWJT 28 (1985) 612 (p. 6); A. Snell, New and Living Way (London: The Faith Press, 1959) 32. W. Manson (The Epistle to the Hebrews, 117) says, "The survey we have now concluded will have made plain the extent to which the epistle to the Hebrews is dominated by one great Old Testament Oracle-Psalm cx.' G.W. Buchanan (To the Hebrews [Anchor Bible Series; Garden City, NY: Doubleday, 1972] xix) makes the dramatic but probably overstated remark: "The document entitled "To the Hebrews" is a homiletical midrash based on Ps. 110.' 
Scripture as a homiletical device in Hebrews can provide useful clues to its structure. For example, it is hard to imagine anyone suggesting a major division between chapters 3 and 4 since the exposition of Psalm 95 extends over the chapter break. In the same way, understanding the use of Psalm 110 can provide some insight into the overall structure of Hebrews since it is used throughout most of the book. Taking notice of our author's use of Scripture, and particularly Psalm 110, helps to establish the limits of the first section of Hebrews, which in turn suggests a structure for the rest of the book:

I. Jesus' fulfilment of Psalm 110:1 and 110:4

A. Jesus' qualifications as Son (1:5-4:16)

(Development of Ps. 110:1)

B. Jesus' dual role as the Son/Priest (5:1-10)

(Connection of Ps. 2:7 and 110:1 with 110:4)

C. Jesus' qualifications as Priest (5:11-7:28)

(Development of Ps. 110:4)

II. Theological implications of Jesus' fulfilment of Ps. 110:1 and 110:4

$8: 1-10: 39$

III. Practical implications of Jesus' fulfilment of Ps. 110:1 and 110:4

$11: 1-13: 25$

\section{Structure and the Rhetorical Character of Hebrews}

'While the author of Hebrews is not a philosopher, it is undeniable that the book is the work of a skilled rhetorician.'21 Hebrews is perhaps the most rhetorically polished text in the New Testament, and Harold Attridge finds no less than thirteen rhetorical devices: alliteration, anaphora, antithesis, assonance, asyndeton, brachylogy, chiasm, ellipse, hendiadys, hyperbaton, isocolon, litotes, and paronomasia. 22 Recognising the rhetorical character of Hebrews has advanced the study of its structure, especially in the light of the work of Wills and Albert Vanhoye, who offer some helpful insights.

21J.W. Thompson, The Beginnings of Christian Philosophy: The Epistle to the Hebrews (Washington, D.C.: The Catholic Biblical Association of America, 1982) 158.

${ }^{22}$ Attridge, The Epistle to the Hebrews, 20. 
The word-of-exhortation form as described by Wills and employed by our author has obvious implications for the study of the structure of Hebrews, since the repetition of the exempla-conclusion-exhortation pattern can give some clue as to the limits of certain sections. ${ }^{23}$ I shall refer to Wills' interpretation of these cycles in Hebrews at critical points in this discussion.

The work of Vanhoye is shaped largely by his application to the book of Hebrews of what he terms the 'structuralizing techniques of composition'. According to him, our author employs several literary techniques for marking out the structure of his sermon:

Announcement of the subject to be discussed [e.g., 1:1-4]; Inclusions which indicate the boundaries of the developments [e.g., 3:1 and 4:14];

Variation of literary genre: exposition or paraenesis [e.g., 2:1-4];

Words which characterise a development [e.g., angels in chs. 1 and 2];

Transition by immediate repetition of an expression or of a word which is termed a hook word [ e.g., Melchizedek in ch. 7];

Symmetric arrangements [1:5-14 and 2:5-18].24

The most important of these techniques, in Vanhoye's estimation, is the announcement of subject. According to him, our author used this technique in conjunction with the others to indicate the structure of his homily, avoiding the coarse method of counting out his points, relying on the insight of his readers to recognise more artistic and subtle literary clues to the structure of his work. 25

${ }^{23}$ Wills, 'The Form of the Sermon in Hellenistic Judaism and Early Christianity'.

24Vanhoye, Structure and Message of the Epistle to the Hebrews, 20. Cf. Vanhoye's La Structure Littéraire de l'Épitre aux Hébreux (Paris: Desclee De Brouwer, 1963) 37, where he lists the first five of these literary indices, not including 'symmetric arrangements' in his list of fully fledged 'structuralizing techniques' until his later English treatment.

25In Vanhoye's scheme (La Structure Littéraire de l'Épitre aux Hébreux, 5963) the structure of the book of Hebrews as a whole forms an elaborate chiasm. 
Vanhoye is correct in his observation that our writer gives few overt clues to the structure of his work, and it is easy to find examples of the more subtle structuralising techniques in Hebrews. Furthermore, it is possible to build an outline of the book on the basis of his theory. So, has someone finally devised a 'scientific', or at least literary method for solving the problem of the structure of Hebrews? If so, this should greatly reduce, if not end, the disagreement. But it does not, for now there is disagreement over whether or not Vanhoye is right. Some, including Black and Hugh Montefiore, believe he has got it right, ${ }^{26}$ but many, among whom Swetnam has probably given the most thorough and gracious evaluation, 27 do not accept the analysis of Vanhoye. In the end, Vanhoye's observations do have much to be commended, and should at least be considered in the process of evaluating the clues to the structure of Hebrews, but they probably do not offer the final solution, as they might initially appear to do. The reason for this is that the task of recognising Vanhoye's 'structuralizing techniques' in Hebrews is not as objective as it might seem. If a section of Hebrews, for instance 3:1-5:10, is announced at the end of the previous section (in this case 2:17, 18), marked out by inclusion, change of genre, characteristic words and symmetry, who could argue that it does not comprise a structural unit? However, one can pose an alternative scenario by discovering a different set of structural clues: a different announcement of subject in the previous section, a different inclusion and so on, and this is quite possible (which I will demonstrate later). So if two interpreters do not recognise the same structural clues, it is probable that at least one is not in touch with what the author had in mind. Then, along with the subjective element in the task of defining structural clues, the interpreter must also determine whether a particular clue marks out a main division or

26Black ('The Problem of the Literary Structure of Hebrews: An Evaluation and a Proposal', 168-175) says, 'Vanhoye's analysis has much in its favor and is due more attention than it has received' (p. 169); Montefiore, $A$ Commentary on the Epistle to the Hebrews (Black's New Testament Commentaries; London: A. and C. Black, 1964) 31.

27Swetnam, 'Form and Content in Hebrews 1-6', Bib 53 (1972) 368-385; and

'Form and Content in Hebrews 7-13', Bib 55 (1974) 333-348. 
a subdivision. This decision, which establishes structural relationships, cannot be made in isolation from the reader's interpretation of the book's content. Finally, it is important to bear in mind that the 'techniques' Vanhoye defines as structural clues can also be used as literary devices which have nothing to do with the structure of the composition. Therefore, some judgement must be made as to whether any given device is intended as a structural marker or is simply there for persuasive effect.

Since Vanhoye's approach of relying on literary devices does not avoid the subjective element which is a part of any interpretative enterprise, it does not represent a fail-safe method for determining structure. Therefore, it seems prudent to consider all the factors that may have a bearing on the issue of structure, not the least of these being content. This is Swetnam's main criticism of Vanhoye, that he does not give proper consideration to content.

But worthy as this attention to form is, there is a concomitant danger which should not be overlooked: if form is too much divorced from content it can lead to a distortion of content, not a clarification. ${ }^{28}$

It seems reasonable to conclude that content is an important factor, if not in the establishment of structure itself, then at least in the interpretation of literary devices. But surely, any proposed structure of Hebrews must not be at odds with its content, and therefore must be derived from content, at least in part. Swetnam's correction, then, must be taken, that the structure of Hebrews must be analysed 'with attention being paid to both form and content' ${ }^{29}$

\section{The Structural Implications of Rhetorical Study}

Both form and content are important for determining the structure of Hebrews. In fact, if the primary goal of the author was to communicate a message, and structure is one device by

${ }^{28}$ Swetnam, 'Form and Content in Hebrews 1-6', 369.

${ }^{29}$ Swetnam, 'Form and Content in Hebrews 1-6', 369. 
which he could accomplish this goal, then structure should be viewed as the servant of content, and therefore as determined by it. However, form and content are not the only structural considerations. Literary genre, I submit, also plays a formative role in the structural development of Hebrews, not genre as mentioned by Vanhoye-'exposition or paraenesis'-but the broader question of the genre of the book as a whole. ${ }^{30}$ Nonetheless, formal considerations can be very useful structural indicators, and an outline derived from them can be very instructive.

The first structural seam of Hebrews comes after 1:4. This is indicated by a change from the compact and highly poetical style of verses $1-4$ to the rapid-fire quotation of Scripture forming the catena in verses 5-14. This division is also indicated by the announcement of subject in verse 4 , which is that the Son is superior to the angels. This comparison of Christ to the angels continues through 2:18, with the characteristic word ơ $\gamma \gamma \varepsilon \lambda \circ \varsigma$ appearing throughout the section. This section, from 1:5-2:18, is divided in two by the warning in 2:1-4. The next section, which begins at 3:1, is announced in 2:17, 'in order that he might be a merciful and faithful high priest in service to God, for the propitiation of the sins of the people'. Jesus is shown to be faithful in 3:1-6, and merciful in 4:14-5:10. Chapter 7, which details God's appointment of Christ as high priest in the order of Melchizedek, is announced by the phrase in 2:17 'in service to God', and the phrase 'for the propitiation of the sins of the people' announces what would come in chapters 8-10. The admonition which starts in 5:11 marks the beginning of a new section, scolding the readers for their immaturity. Since the previous section ends with the words 'designated by God high priest according to the order of Melchizedek', it is reasonable to entertain the idea that this section ends at $6: 20$ with the similar phrase 'according to the order of Melchizedek he has become high priest forever'. That is, it seems that this section

${ }^{30}$ That is, if Hebrews is an exegetical homily based on Ps. 110:1, 4, then the author's development of these verses may, and in fact do, influence the structure of the book. 
stands as a digression in the author's argument, 31 meant to prepare the readers for what would follow, and if this section is a digression, the near repetition of the end of the previous section at the end of this digression may be the author's way of helping himself and his readers back into the flow of his argument, which would resume at 7:1. A further indication that 5:11-6:20 forms a unit is that, although it does remain connected to the context by the oath theme which can be found both before and after the digression, it does not follow directly from the apparent announcement of subject in 5:9, 10.32 Vanhoye understands this announcement as tripartite: 1) being made perfect, anticipating chapters 8 and 9,2) he became a cause of eternal salvation, anticipating 10:1-18, and 3) he is designated high priest in the order of Melchizedek, anticipating chapter 7. However, this does not seem to fit the content of chapters 8 and 9, which more naturally fit together with 10:1-18, showing Christ as a cause of eternal salvation. It may be better to understand the participle 'made perfect' in verse 9 as looking back to what has gone before, and the announcement as consisting of three different parts: 1) to all those who obey him, anticipating chapters $11-13,332$ ) a cause of eternal salvation, anticipating chapters $8-10$, and 3) appointed by God high priest according to the order of Melchizedek anticipating chapter 7. This understanding of the announcement of subject in 5:9, 10 would stand against the divisions suggested by Vanhoye, because it provides no justification for grouping chapters 7-10 as a structural unit. Wills' understanding of 8:1-10:25 as a complete cycle of the word of exhortation form also stands against Vanhoye's grouping of chapters 7-10, since chapter 7 does not follow the word of exhortation pattern. ${ }^{34}$ This change of genre between chapters 7 and 8 affirms the presence of a structural seam at this point.

${ }^{31}$ Cf. F.D.V. Narborough, The Epistle to the Hebrews (The Clarendon Bible; Oxford: Clarendon, 1943) 102-106.

$325: 8$ looks back to the previous context (i.e. $2: 10,18 ; 4: 15$ )

${ }^{33} \mathrm{Cf}$. 11:8, the concept of fatherly discipline in 12:7-11, and 13:7.

34Wills, "The Form of the Sermon in Hellenistic Judaism and Early Christianity', 282. 
Chapter 7 is clearly a unit unto itself, with characteristic

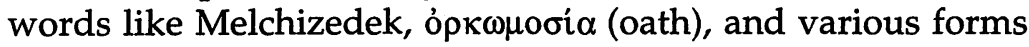
of $\tau \varepsilon \lambda \varepsilon \imath$ io $\omega$ (to complete), along with repeated references to Psalm 110:4. If we continue to follow the announcement of subject in $5: 9,10$, then chapters $8-10$ also form a unit, and this can be verified by several structural clues within this section. First, these chapters include one longer section of theological discourse and one shorter section of paraenesis, both of which use a form of $\varepsilon \chi \omega$ at or near the beginning. Further investigation reveals that there are several words in the first sentence of the theological part that correspond to words in the first sen-

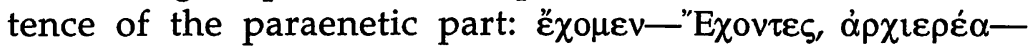

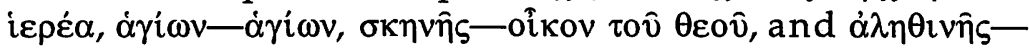
$\dot{\alpha} \lambda \eta \theta \imath v \eta \bar{\eta}$. This list of words or similar words common to the first sentences of these two parts may indicate a structural connection, that is, that the paraenetic part (10:19-39) should be seen as connected to the doctrinal part (8:1-10:18). Secondly, the repetition of parts of Jeremiah 31 in chapters 8 and 10 serves to bind the doctrinal part of these chapters together with an inclusio. Thirdly, understanding 8:1-10:25 as forming a cycle of exempla (8:1-10:18), conclusion (10:19-21) and exhortation (10:22-25) indicates that these chapters must be a unit. Fourthly, fourteen of the seventeen occurrences of $\delta \imath \alpha \theta \dot{\eta} \kappa \eta$ in Hebrews occur in chapters 8-10, making it a characteristic word in this section. Fifthly, the word 'faith' serves as a hook word in 10:39 and 11:1, marking out a structural seam, just as the word 'Melchizedek' serves as a hook word in 6:20 and 7:1 and has a similar function.

The last three chapters, 11-13, are set apart from the rest of the book by virtue of genre. The development of doctrine and theology which makes up the bulk of the first ten chapters and provides a foundation for paraenesis is nearly absent from the last three (though 12:18-29 repeats the earlier pattern in miniature). Instead, these chapters rely on both positive and negative examples from the past as a spring board for paraenesis. The first section in these last three chapters, 11:1-12:3, forms a discourse on faith, with faith serving as a characteristic word for that section. The limits of this section are defined quite clearly, with 11:4-38 as exempla, 11:39, 40 as the conclusion and 
12:1-3 as the exhortation. The next division is indicated less clearly in terms of structural clues. A structural seam may be indicated at $13: 1$ by the cluster of exhortations in 13:1-6remain, do not forget, remember, let it be, and let it be. But more important is the anticipation of a tripartite structure for the last three chapters found in 10:22-25, which constitutes an announcement of subject. The faith theme of 11:1-12:3 is anticipated in 10:22, 'let us approach with true hearts in full assurance of faith'; the endurance theme of 12:4-29 is anticipated in 10:23, 'let us hold fast the confession of hope without wavering'; the theme of Christian sacrifice (works) in chapter 13 is anticipated in 10:24, 25, 'consider one another for the stimulation of love and good works'. Therefore, it seems best to understand $11: 1-12: 3,12: 4-29$ and $13: 1-19$ as forming three units that make up the last main section of Hebrews. The final two divisions of the book are clearly marked out by genre. Hebrews 13:20, 21 is a benediction, and 13:22-25 constitutes an epistolary closing.

On the basis of this analysis a rough outline of Hebrews emerges which shows several main divisions and subdivisions:

Prologue

I. Jesus superior to the angels

A. Superior in divinity (1:5-14)

B. Warning (2:1-4)

C. Superior in humanity $(2: 5-18)$

II. Jesus a faithful Priest

III. Jesus a merciful Priest

4:14-5:10

IV. Digression (Readers' unpreparedness for teaching on the subject announced because of immaturity)

$5: 11-6: 20$

V. Jesus in the order of Melchizedek

VI. Jesus a cause of eternal salvation

A. A unique Priest which the readers have (8:1-10:18)

B. The consequent responsibility which the readers have (10:19-39)

VII. Jesus as an example of obedience

A. Faith (11:1-12:3)

B. Endurance (12:4-29)

C. Sacrifice (13:1-19)

Benediction

Epistolary closing

$13: 22-25$ 
With regard to the location of the divisions in Hebrews, this evaluation agrees with that of Vanhoye to a large extent, yet I have tried to repeat his most enlightening and detailed analysis as little as possible. There are points at which I disagree with Vanhoye, however, primarily as a result of differing interpretations of announcements of subject. With regard to prioritising these divisions, that is, determining which are the main divisions and which are the subdivisions and thus grouping the sections, Vanhoye's analysis is less helpful. This becomes most evident when factors such as literary genre and content are given greater consideration.

\section{Structure and the Message of Hebrews}

\section{An Interpretation of Hebrews}

It is widely accepted that there are two strands that run through Hebrews, one doctrinal and the other paraenetic, and each of these strands has a distinct focus. To suggest an overall theme for Hebrews, then, it is necessary to distil the message of each strand, consider how these two strands work together to form the whole and then derive a theme that is both specific to and inclusive of the book as a whole. The problem with this procedure is that the demarcation of the two strands is not always absolutely clear, and there is some overlap between them. In the end, however, this will not preclude an acceptable outcome since the interpretation of the parts of the book is not finally determined by how they are labelled, and since the consideration of every part of the book is more important than labelling those parts.

The thrust of the doctrinal sections seems to be superiority: the superior personal qualifications of Jesus in the first seven chapters, the superior ministry of Jesus in the next three chapters and the superior standing of New Covenant believers in the last three chapters. According to 8:1, the main point of the sermon is that Christians have a superior high priest in Christ. It may be argued that $8: 1$ is a reference to one section of the book and not to the whole. Even if this point is taken, and I do not accept it, the fact that the writer is compelled only here 
to make such a clear and succinct statement of his point must indicate that it is central to his thesis. Therefore, the focal point of the doctrinal parts of Hebrews seems to be the priestly work of Christ, which is superior because Jesus himself and his ministry are superior, and which in turn gives New Covenant believers a superior standing. The paraenetic sections are dominated by the readers' need for fidelity to their commitment to Christ. Our author is concerned to encourage his readers to be faithful to Christ and enjoy the blessing of God rather than slipping away and facing God's judgement.

Since it is reasonable to understand the paraenetic sections as growing out of and being supported by the doctrinal parts, a synthesis of the two should yield an acceptable understanding of the overall message of the book. This synthesis is accomplished by answering the question: what does Christian fidelity have to do with the priesthood of Christ? For our author, Christian fidelity means fidelity to the new relationship with God mediated by Christ (e.g., 9:11-16), and this fidelity is necessary and reasonable in the light of Christ's priestly ministry (e.g., 10:19-39). Hence, the message of Hebrews simply stated is, 'Christ's priestly ministry demands fidelity to the new relationship with God that he mediates.' Fidelity to this new relationship, or New Covenant, is more than doctrinal commitment for our author; it includes confidence in Christ's ministry both past and present as well as willingness to follow and obey him whatever the cost. Christ's New Covenant ministry revolves around his priestly work, which supersedes the Old Covenant ministry of the priests in the earthly tabernacle. Clearly, our writer means to persuade his readers to place their trust in the priestly ministry of Christ when they are accustomed to placing it, at least to some degree, in the ministry of the Mosaic covenant. From this perspective, Hebrews is all about practising faith in God under the New Covenant instead of the Old Covenant.

\section{The Structural Implications of Content}

Hebrews opens with a poetically styled pericope designed to lay a foundation of revelatory authority upon which our author will work. It is the incomplete word of God through the 
prophets of old accompanied by God's final word in his Son 35 that forms the source and authority of his message. 36 The last verse of the opening introduces the first subject of the first section, the superiority of Christ to the angels. Much speculation has gone into explaining the author's reason for emphasising the lower place of angels in chapter one, since it is difficult at first glance to relate the importance attached to angels in this section to the argument of the rest of the book. Some have suggested the readers' religious background as an explanation for the prominence of angels here, for example, protoGnosticism, a connection with Qumran or throne mysticism. It may be that a simpler solution is to be preferred, that the angelic role in the establishment of the Mosaic covenant drew our author's attention to the angels (2:2), 37 which would reflect the same train of thought as his comparisons with the exodus leaders and the Aaronic priests in the following chapters. He begins with the figures (mediators) that have the closest contact with God-the angels-and works out from there-Moses, Joshua and then Aaron and the priests. In the catena of Scripture quotations that makes up the bulk of chapter one, our author accomplishes two main objectives. First, he shows that Jesus is superior to the angels because he is divine. Secondly, he shows that it is Jesus the Son who is referred to in Psalm 110:1, an important connection for him since he will found the book's argument on his exegesis of Psalm 110, but will prefer to speak in terms of the Son ( $c f .5: 5,6 ; 7: 28) .38$

${ }^{35}$ Cf. R. Williamson ('The Incarnation of the Logos in Hebrews', ExpT [1982-83] 4-8 [p. 7]) who says, "The argument of Hebrews also makes it clear that the "Word" spoken "by a Son" was made up of the whole life, words and, more importantly, deeds of Jesus. And the opening section of chapter one implies a clear distinction between God's previous "words" and his final "Word".'

${ }^{36} \mathrm{Cf}$. Lindars, 'The Rhetorical Structure of Hebrews', 387.

37See Ex. 23:20-24. Cf. Hurst, The Epistle to the Hebrews, 46.

${ }^{38}$ Lindars ('The Rhetorical Structure of Hebrews', 391) explains one important aspect of the Son connection to our author: 'He then reveals why he has devoted so much space in his opening statement to the contrast between the messianic Son of God and the angels. It is because of the humanity of Jesus, which is essential to salvation, for otherwise he would not have died a human death. Though the point is not taken up 
Chapter 2 opens with the book's first warning: if the message brought by angels was binding, how much more the message brought by the Son. This seems to sum up the importance of the angels in this section as being mediators of God's message to humanity, which affirms the conclusion that our writer understands the angels as involved in the establishment of the Mosaic covenant. The superiority of Christ over the angels, then, has important implications for the Christian's relationship to the Mosaic covenant, implications which the author develops later in the book. The rest of chapter 2 is spent showing the superiority of Christ to the angels because he is human. Jesus' humanity allows him to fulfil the place of dominion given to humanity, although our author is very careful to point out that this dominion, though certain, has not yet been fully accomplished. Jesus' humanity also allows him to suffer and die in the place of his 'brothers', and to help them through their temptations. The first two chapters, then, assert that Christ is superior to the angels, first because he is divine, and secondly because he is human, therefore it is all the more important to heed his message.

A comparison of Christ to Moses begins chapter 3. They are both declared faithful, Moses as a servant in the house of God, Christ as a Son. The rest of the chapter develops a comparison between the people of the exodus and the readers themselves, or, more precisely, a warning to the readers not to follow the example of disobedience set by the children of Israel. This comparison between the two peoples continues into chapter 4 , and assumes a great deal of continuity between the two, especially in the basic necessity for faith and obedience. ${ }^{39}$ While chapter 3 and the first part of chapter 4 highlight the need for faith and obedience, as described in Psalm 95, the middle section of chapter 4 takes up the theme of entering God's rest, which is the final point of the Psalm 95 quotation. Joshua enters the picture with the theme of rest, so that Jesus is presented as superior to both of the exodus leaders, and his followers are

immediately, it is an indispensable prerequisite for the later exposition of the purification of sins.'

${ }^{39}$ See R.V.G. Tasker, The Old Testament in the New Testament (rev. ed.; London: SCM, 1954) 107. 
expected to exceed the faith and obedience of the exodus generation. Just as the superior faithfulness of the Son is compared to the faithfulness of Moses and Joshua in 3:1-4:13, it is the superior mercy of the Son that is compared to Aaron and the Aaronic priests in 4:14-5:10. Jesus' mercy is seen to be more deliberate and helpful since it flows from temptations and suffering common to humanity, and since he successfully withstood that temptation and suffering and did not sin. Because of this, he should be seen as both a merciful and faithful high priest.

Priesthood and related matters will dominate the next several chapters. In chapter 5 the writer makes his first explicit identification of Christ as the referent of both Psalm 110:1 and Psalm 110:4. He speaks of the Son who is a priest in the order of Melchizedek, since he has already established in the first chapter that Psalm 110:1 is about the Son. After introducing the subject of the priesthood after the order of Melchizedek, the author inserts a warning against slackness which begins at the end of chapter 5 and runs through chapter 6 . Since this section (5:11-6:20) forms a digression, it is best to understand the flow of the main argument as moving from the order of Melchizedek at 5:10 to the order of Melchizedek at 7:1. Chapter 7 brings the readers to a proper discussion of Melchizedek and a creative proof that the priesthood of Christ is superior to that of the Levites. The logic of chapter 7 fits neatly into a syllogistic form, whether or not the writer was thinking in these terms: Melchizedek is a priest superior to the Levites (vv. 1-10); Christ is a priest after the order of Melchizedek (vv. 11-17); therefore, Christ is a priest superior to the Levites (vv. 18-28). With the close of chapter 7 , the author has accomplished his first main exegetical point: Christ is both the Sovereign Lord referred to in Psalm 110:1 and the priest referred to in Psalm 110:4, and as such he is superior to all those associated with the Mosaic covenant, especially the priests.

The focus on the players of the exodus in the first seven chapters is met by a corresponding focus on the covenant of the exodus in the next three chapters. Just as Jesus' personal and priestly qualifications are compared to those of the exodus figures in chapters 1-7, his New Covenant priestly work is compared to the Old Covenant ministry of the exodus priests in 
chapters 8-10. Throughout this comparison covenant and sacrifice are central issues, since both the Levites' and Jesus' priestly sacrifices are seen as mediating their respective covenants. Chapter 8 serves as an introduction to the middle section of Hebrews, with the first verse providing a transition from chapter 7 and the rest of the first section of the book. The introductory function of chapter 8 is indicated by the fact that the overarching theme of chapters 8-10 (Christ's priestly work) is encapsulated in chapter 8: all of the main topics dealt with in this section (the relationship of Christ's priesthood to sanctuary, sacrifice and covenant) are introduced in chapter 8 , and there is no topic in chapter 8 that is not dealt with again in chapters 9 and 10. Chapter 8, which features the New Covenant as the basis for Christ's priestly work, goes a step further than the author previously has in impugning the old, Mosaic system. 40 The trappings of the levitical priesthood are compared to Christ's priestly ministry in chapters 9 and 10 . The first 14 verses of chapter 9 recall the old order of the tabernacle, calling it 'a parable for the present time'. Verses 15-22 of chapter 9 compare the new covenant to its Mosaic counterpart, emphasising the importance of blood in the inauguration of both covenants. In 9:23-10:18 the author compares the sacrifices of the Old Covenant with that of Christ's under the new. In this section, he traces the relationship between the tabernacle and sacrifice in 9:23-28, where animal sacrifices serve to cleanse the earthly tabernacle and Christ's sacrifice cleanses the heavenly sanctuary, with 10:1-18 explaining the superior effectiveness of Christ's sacrifice to deal with the sin problem of the people, in comparison to the levitical sacrifices. Christ's sacrifice is superior in that it is a once-for-all offering and is permanently effective. The last part of chapter 10 (vv. 19-39) applies the doctrinal content of chapters 8-10 in a section of paraenesis, including a warning. The readers' confidence before God is our author's primary burden here as he encourages his readers to draw near to God through the curtain and into the most holy place by way of Christ's sacrifice. The warning (10:26-31) is of the judgement

${ }^{40} \mathrm{Cf}$. R.E. Clements, 'The Use of the Old Testament in Hebrews', SWJTh 28 (1985) 36-45 (p. 44). 
of God for those who choose to continue sinning, or rejecting the covenant God has made with his people. Chapter 10 closes by stressing the importance of confidence (vv. 32-39), as expressed through enduring sacrifice in the light of Christ's parousia, and reviews the three main doctrinal topics covered in the previous section: sanctuary, covenant and sacrifice. Since 10:19-39 is the only paraenetic section in chapters $8-10$, and since it focuses on the readers' confidence before God, confidence seems to be the underlying concern of the author in chapters 8-10.

The beginning of chapter 11 marks a dramatic shift in subject matter. The topic of priesthood, which dominates the first ten chapters, is rarely broached in the last three. Instead, the focus has shifted to Christian virtue: faith, endurance and sacrifice. Whereas chapters 1-10 concentrate on Christian responsibility in the light of the superior nature of what God has done in Christ, chapters 11-13 concern themselves with Christian responsibility in the light of the example of Jesus and others. 41 These examples include the saints of old who exemplify faith, as examined in chapter 11 . Faith is such a strong theme in this chapter that a vital component of the argument can be overlooked, that these examples had unwavering faith in spite of not having experienced the ultimate fulfilment of God's promise. This point is consistent with a strand that runs through the book. That all things are not yet put under Christ's subjection comes up in 2:8 and 10:13, as does the postponement of reward and the fulfilment of promise in 10:35-39. The exodus/pilgrimage theme also lines up with this concept of delayed fulfilment. Clearly, the possibility of a delayed but certain fulfilment of God's promise is an important concept to our author. This discussion of faith concludes with 12:1-3 where Jesus, the very author and perfecter of faith, is offered as the ultimate example of faith for the readers and one to whom they must look.

The rest of chapter 12 is concerned with endurance. According to 12:7 the readers were to endure for the sake of discipline, which indicates that they must have been facing some difficulty. That the readers' suffering may be coming

41With the exception of 12:18-24 and possibly 13:10-14. 
from God in the form of fatherly discipline is offered as encouragement to continue in perseverance, which would result in maturity. Two negative examples form the focal points of a warning against failing to endure: Esau selling his birthright, which illustrates the foolishness of not enduring, and the Israelites before Mount Sinai, which illustrates the relative ease of Christian endurance before God in Christ and the greater responsibility of New Covenant believers to the Christian message because it gives them a direct connection to the heavenly realities. The chapter ends with a call to gratitude and reverence in the light of having received an unshakeable kingdom. This reference is similar to those in chapter 11 which speak of a heavenly country and city (vv. 10,13-16).

Faith enables endurance, and endurance undergirds obedience. In chapter 13 the priesthood of Christ comes to the fore once again as the author explains that New Covenant believers are to offer sacrifices to God through Christ (vv. 15, 16). 42 These sacrifices are praise, good deeds and fellowship, which represent a broad range of Christian activities, and are clearly intended to take the place of levitical sacrifices for the readers (cf. vv. 9, 10). Seen in this light, the several exhortations at the beginning of chapter 13 provide a more detailed description of the sacrifice of good deeds, or Christian obedience, and establish it as an important part of the readers' Christian commitment. That the readers continue in obedience to their Christian commitment and be willing to sacrifice for the sake of others and in service to God as illustrated by Christ 'outside the camp' must have been our author's utmost concern. But he was not interested in blind obedience, as verses 5 and 6 and the broader context of Hebrews show, but a sacrificial commitment to obey God that flows from understanding and faith. The homily ends with a benediction recalling some of the main points of the argument: covenant, completeness and obedience. It is interesting that the priesthood theme is not prominent in this benediction, but that Christ's resurrection, which is not mentioned earlier, is. However, the benediction does reflect the dual emphasis of the book: affirming the sufficiency of what

${ }^{42} C f$. also Phil. 4:8 and 1 Pet. 2:5. 
God has done in Christ, and the responsibilities of those who follow him. The beginning of Hebrews shows no epistolary characteristics, but its ending is typical of the New Testament letters. The conclusion that Hebrews is a sermon which was sent to an audience some distance away, an epistolary homily, is consistent with this observation.

Finally, having considered issues related to Hebrews' literary genre, its rhetorical character and its content, it is possible to develop an outline that reflects all three of these perspectives, with emphasis given to content:

Prologue

I. The Sovereign Son as Superior Mediator

A. A Mediator Superior to the Angels (1:5-2:18)

1. Superior because of his Divinity (1:5-14)

2. The Superior Demand of his Message (2:1-4)

3. Superior because of his Humanity (2:5-18)

B. A Mediator Superior to the Exodus Leaders (3:1-5:10)

1. Superior to Moses and Joshua in Faithfulness-the Readers' Need for Faith (3:1-4:13)

2. Superior to Aaron in Mercy-the Readers' Need for Confidence (4:14-5:10)

(3. Immaturity of the Readers-5:11-6:20)

C. A Mediator Superior to the Levitical Priests (7:1-28)

1. The Superiority of Melchizedek to the Levites (7:1-10)

2. The Appointment of Jesus in the order of Melchizedek (7:11-17)

3. The Superiority of Jesus to the Levites (7:18-28)

II. The Superior Ministry of the New Covenant Mediator 8:1-10:39

A. Introduction to Christ's New Covenant priestly ministry (8:1-13)

B. An explanation of Christ's New Covenant priestly ministry (9:1-10:18)

1. The Old and New Sanctuaries compared (9:1-14)

2. The Old and New Covenants compared (9:15-22)

3. The Old and New Sacrifices compared (9:23-10:18)

C. Paraenesis based on Christ's New Covenant priestly ministry (10:19-39)

1. Confidence to enter the sanctuary (10:19-25)

2. Judgement for rejecting God's covenant (10:26-31)

3. Reward for enduring sacrifice (10:32-39) 
III. New Covenant requirements for the people of God 11:1-13:19

A. Faith in spite of delayed promises (11:1-12:3)

B. Endurance for the sake of God's discipline (12:4-29)

C. Obedience in a context of sacrifice (13:1-19)

Benediction

$13: 20,21$

Epistolary Closing

$13: 22-25$ 